\title{
Exploring capability and accountability outcomes of open development for the poor and marginalized: An analysis of select literature
}

\author{
Caitlin M. Bentley
}

\section{Arul Chib}

\section{Sammia C. Poveda}

Nanyang Technological University, Singapore

Corresponding Author.

caitlin.bentley@gmail.com

Nanyang Technological University, Singapore

ArulChib@ntu.edu.sg

Sheffield University, United Kingdom

s.c.poveda@sheffield.ac.uk

Open development concerns the application of digitally-enabled openness to radically change human capability and governance contexts (Davies \& Edwards, 2012; Smith \& Reilly, 2013; Smith, Elder, \& Emdon, 2011). However, what openness means, and how it contributes to development outcomes is contested (Buskens, 2013; Singh \& Gurumurthy, 2013). Furthermore, the potential of open development to support positive social transformation has not yet materialized, particularly for marginalized populations (Bentley \& Chib, 2016), partly because relatively little is known regarding how transformation is enacted in the field. Likewise, two promising outcomes - the expansion of human capabilities and accountability - have not been explored in detail. This research interrogates the influence of digitally-enabled openness on transformation processes and outcomes. A purposeful sample of literature was taken to evaluate outcomes and transformation processes according to our theoretical framework, which defines seven cross-cutting dimensions essential to

Bentley, C., Chib, A., Poveda, S. (2017). Exploring capability and accountability outcomes of open development for the poor and marginalized: An analysis of select literature. The Journal of Community Informatics, 13(3), 98-129.

Date submitted: 2017-10-26. Date accepted: 2017-12-26.

Copyright (C), 2017 (the author as stated). Licensed under the Creative Commons AttributionNonCommercial-ShareAlike 2.5. Available at: www.ci-journal.net/index.php/ciej/article/view/1423 
incorporate. We argue that these dimensions explain links between structures, processes and outcomes of open development. These links are essential to understand in the area of Community Informatics as they enable researchers and practitioners to support effective use of openness by and for poor and marginalized communities to pursue their own objectives.

\section{Introduction}

In the past ten years, many approaches to development have emerged utilizing networked Information and Communication Technologies (ICT) to expand opportunities for people to share and reuse information, or to participate in governance, collaboration or production activities within communities. Digitally-enabled openness, shortened to openness in this article, focuses on specific processes and characteristics of public sharing and production of information and communications resources through the use of networked ICTs (such as crowdsourcing, peer production or public sharing of information) (Smith \& Seward, 2017). Open development is a new field of research and practice that refers to those instances when openness is used within a community development approach. For example, publicly sharing government information has the potential to expand human capabilities when this information is used to enhance public services or to help citizens to engage in community governance activities. It can also strengthen public accountability by increasing transparent and communicative relationships between community-members and government representatives. However, despite the potential for openness to expand human capabilities and to strengthen multiple accountabilities within development processes, research has thus far produced inconclusive results. Evidence to connect openness to the processes and outcomes that transpire is lacking, particularly for poor and marginalized populations (Bentley \& Chib, 2016). We define open development as the free, networked, public sharing of digital (information and communication) resources towards a process of positive social transformation. Thus, we are concerned with whether, how and for whom openness actually makes a difference within poor and marginalized communities.

Given the relatively nascent nature of the field, certain dimensions of open development have not yet been well-defined. So far, new forms of digital communication and information sharing, such as peer production, crowdsourcing, and public distribution of data in machine-readable formats have been the main focus of enquiry. However, other dimensions such as the conception of technology, actors and power relations between them are also at play when determining who stands to gain from open development initiatives, with contrasting perspectives prevailing. For example, within Kenyan slums, where state government has had limited capacity to meet the needs of its poor and marginalized communities, digitally-enabled openness is credited for providing an outlet for citizens and volunteers to crowdsource statistics and points of community interest (Panek \& Sobotova, 2015; Parfitt, Parsons, Gregory, Chiteri, \& Omondi, 2013), and to self-organize community services and expand capabilities through participatory development processes (Hagen, 2011). Kovacic and Lundine (2013, p. 128) argue that these open development outcomes "point to the transformative and influential power of 
technology and the collective's perception of ICT as the connecting factor among the citizens and between the citizens and the state." An alternate critical perspective questions this conclusion. Berdou (2011) argued that citizens were afforded token roles on platforms of participation, and that new technology actors came into the picture. New actors, and elements of community participation, can be signs of transformation in development contexts, but it is not clear that benefits are distributed evenly across community actors. Approaching the issue from the perspective of social justice, one may inquire whether open development is a remedy or a cause for increasing social inequality within communities. We outline seven cross-cutting open development dimensions that can potentially explain transformation, whilst prioritizing the perspectives of poor and marginalized people.

This article critically reviews the literature in a systematic way to disentangle inherent complexities within open development research and practice. Our literature review process included targeting open development research through keyword searches for common open development terms, identifying studies that took place in middle- and low-income countries, and applying inclusion/exclusion criteria to target empirical studies engaging with capability and accountability outcomes of open development. We searched for articles primarily via the SCOPUS database, and key ICT4D journals including the Journal of Community Informatics (JoCI). Several articles from JoCI were included in this analysis, indicating the topic's significant interest to the JoCI readership. The purpose of the article is two-fold: 1) to explain which dimensions are essential to ensure the protection and empowerment of poor and marginalized populations in open development research and practice; 2 ) to critically analyze whether these dimensions explain the distinctly new opportunities and limitations within transformation processes and outcomes of open development. We explore seven open development dimensions for their explanatory potential towards transformational processes and outcomes.

Furthermore, as a means to evade ambiguities about what transformation means and for whom, we focus on two key development outcomes, capabilities and accountability. These outcomes, along with others such as efficiency and innovation, have dominated open development discourses (Gigler, Custer, Bailur, Dodds, \& Asad, 2014; Hodgkinson-Williams et al., 2013; Reilly \& Smith, 2013). However, in a review of 269 open development articles, pervasive empirical problems demonstrated severe lack of gendered and marginalized perspectives (Bentley \& Chib, 2016). We focus on capability and accountability outcomes because they directly relate to structures of power and control that help and hinder poor and marginalized people significantly. This calls into question whether capability and accountability outcomes of open development merely reinforce the status quo. Additionally, researchers frequently failed to articulate reasons why openness makes a difference to development outcomes. One can and should interrogate whether the influence of open development is restricted to individual change, rather than addressing systemic structural issues of existing social imbalances in power.

This article investigates the links between open development dimensions, transformation processes and outcomes. The research question we explore is: In what 
ways do different dimensions of open development shed light on transformation processes and development outcomes? To respond to this question, the article is organized as follows: 1) we outline a theoretical framework for open development dimensions, transformation processes and outcomes (see Table 1);2) we purposefully selected a subset of open development literature emphasizing capability and accountability outcomes; 3) we analyze these studies according to our theoretical framework; and 4) we discuss the implications of our findings.

\section{Theoretical framework}

\section{Towards open development dimensions}

This article builds on a prior literature review which found that the majority of open development literature focuses on specific domains of openness, without engaging with core concepts of what open development means or how it operates (Bentley \& Chib, 2016). Whilst there are many domain specific theories regarding openness, Smith and Reilly's (2013) book is one of the only that has tackled open development theory. It remains a key resource that is widely cited within the literature. Smith and Reilly (2013) outlined seven cross-cutting themes of open development which were derived from analyzing the research within their book: 1) open development is about development outcomes first and foremost; 2) openness has many co-existing and intersecting layers; 3) openness can be disruptive, due to its unique processes and characteristics; 4) openness requires structure to function well; 5) the potential openness affords is never the reality due to the power and position of actors; 6) that openness requires a critical perspective; and 7) that open development is a complex process. However, given these themes were drawn out through a grounded analysis of largely theoretical research, they did not propose these themes as a way in which open development impact could be more thoroughly investigated. In this article, we focus specifically on development impact for poor and marginalized populations, thus we consider whether and how the seven cross-cutting themes might be re-organized for greater coherence and methodological rigor. First, we suggest that four of the themes help to conceptualize socio-technical and structural imbalances. These include: 1) power dynamics; 2) the actors: winners and losers; 3) the social-embedded context of technology; and 4) the processes and characteristics of openness. Second, are the themes that inform the methodological approach to understanding socio-technical and structural imbalances. These are: 5) the multiple levels of analysis required; 6) critical reflexivity; and 7) the multi-dimensional nature of openness. We investigate whether or not these themes are critical dimensions of open development key to understanding impact on poor and marginalized populations.

\section{Power dynamics}

Tensions within open development are inherently shaped by power relations between actors and contexts. Optimistic arguments center on the potential of openness to disrupt disadvantageous power imbalances. Thompson (2008) posited that open access networks imbue horizontal organizing structures, and distinct modes of self- 
organization and collaboration. Such architectures of participation potentially change power relations because decision-making and collaboration processes are guided by decentralized and self-organizing structures rather than directed in a centralized and topdown manner. In contrast, Singh and Gurumurthy (2013, p. 176) argued that there is the tendency to "overlook the ever-present dimension of [how] power manifest[s] in new forms of networked relationships. The outward appearance of access, participation, and collaboration can mask less desirable social and political outcomes undermining equity and social justice." The production of power, and its structural and relational forms are likely vital to examine. It is yet unclear how and whether open development fundamentally changes structures of unequal power relations, and if so, in which direction.

\section{Actors: Winners and losers}

Much of the controversy identified by open development research stems from who stands to gain from openness (Buskens, 2011; Gurstein, 2010a). Open data discourses regularly assume that a trickle-down effect will occur once adequate infrastructure is in place (Brito, Costa, Garcia, \& Meira, 2014; González, Garcia, Cortés, \& Carpy, 2014). Forte and Lampe's (2013) open collaboration model assumes a low barrier to entry. However, Gurstein's (2010a) critique that access does not equate to effective use of open resources continues to be a central challenge within open development. Solutions to protect and empower marginalized perspectives in open development have not yet materialized. For instance, Van Der Windt (2013) investigated a crowdseeing model to overcome participation barriers in Sierra Leone. The aim was to identify an intermediary that supported marginalized people in rural communities so as to enable all citizens to share their voice. The intermediary observed communities and shared back through the crowdseeing application on behalf of the citizens. Some of these representatives pursued their own interests, whilst others became targets of harassment. In accordance with Reilly and Alperin (2016), intermediaries can both enable and aggravate practice contexts. It is necessary to gain a comprehensive understanding of actors, both winners and losers to shed light on these issues.

\section{Social-embedded concept of technology}

Theoretical development in information studies has informed a conception of technology as constitutively entangled with its context (Avgerou, 2001; Avgerou, Ciborra, \& Land, 2004). In order to understand links between transformation processes and outcomes, it is necessary to understand how technology substantially reconfigures contexts and practices and vice versa (Orlikowski, 2007). This implies a need to understand how technology is intertwined within wider social and political systems beyond immediate practice contexts (Leonardi \& Barley, 2008). Open development research has reflected a similar pattern over time. A majority of open development research has focused on technology tools and adoption patterns (Bentley \& Chib, 2016). However, open technologies mean different things and are enacted differently across contexts (Gurstein, 2012). These findings support Buskens' (2013) view that positive transformation requires situating open technologies within their historical and political 
contexts. There is a growing need for understanding sociocultural contexts as a precursor and determinant of open development initiation and related outcomes. In other words, what are the social systems within which open development initiatives are embedded?

\section{Processes and characteristics of digitally-enabled openness}

The contours of digitally-enabled openness have typically been loosely defined in open development. Pomerantz and Peek (2016) argued that openness was once well defined, and structures like open licenses and open source software had specific meaning but are now applied widely, inciting ambiguity and mis-interpretation. In open development, Smith and Elder (Smith \& Elder, 2010, p. 66) first defined open development as:

1. Universal over-restricted access to information, means of communication and ICT tools;

2. Universal over restricted participation in governance/ informal \& formal groups/ institutions;

3. Collaborative over centralized production of cultural, economic, or other content.

This definition is problematic for delimiting open processes because the boundaries and relationships between the three aspects are not clear. Smith and Seward (2017) have since refined this view to create a typology of open social praxis including: open production (e.g. peer production and crowdsourcing), open distribution (e.g. sharing with an open license or freely), and open consumption (e.g. making use of, reusing, or remixing content). These structures provide more detail regarding how and why openness is applied in context.

Alternatively, Singh and Gurumurthy (2013) take a critical stance on the cultural and political contexts of development, and argue that structures of openness should not be taken out of these contexts. They view that institutional structures needed to protect and empower marginalized people must be included in openness structures. They later proposed that open structures are defined by networked activities within a continuum of two types of spaces: 1) community spaces, and 2) organizing spaces (Gurumurthy \& Singh, 2016). Presumably, these denote differences in the form of participation that marginalized people enact, but have yet to clarify distinctions.

\section{Multiple levels of analysis}

Open structures, such as crowdsourcing, or open data distribution, often share certain process characteristics that require multiple levels of analysis to discern the consequences of actions (and inactions). Open structures typically enable resources to be freely accessed and used. They do not intentionally impose barriers or constraints to participate. However, certain stakeholders, particularly the marginalized, need extra support or confront additional barriers to participate, which contradicts the effectiveness of the way open processes are enacted. Another characteristic of open processes is 
emergence, which means outcomes can be either reducible or irreducible to their component parts and procedures (Stephan, 1997). For instance, some aspects of policy reform in Egypt due to Harrassmap can be traced to individuals who shared their experiences that were aggregated to create a richer picture of violence against women, whilst other more substantial outcomes were due to their very broad set of mobilization activities which are harder to reduce to component parts (Young, 2014). These characteristics and contradictions imply that both holistic and targeted analyses may be required to determine the contributions of openness to transformation.

\section{Critical reflexivity}

All of the above dimensions indicate sources of tensions within open development without straightforward solutions. There is therefore a need to examine our actions and assumptions as we attempt to resolve these tensions whilst uncovering new ones. Such a need is consistent with the intent of critical information systems research because researchers are concerned with changing social realities for the better (Orlikowski \& Baroudi, 1991; Stahl, 2008; Walsham, 2005). This may involve tackling topics related to empowerment and emancipation of individuals, addressing power relations or changing social, political and economic structures (Stahl, 2008). It may also involve adopting particular theoretical frames, or research design approaches (Walsham, 2005). In contrast, Eyben (2014) argued that development researchers should internalize reflexive practice skills, such as a critical consciousness of marginality, dialogue, power and contradictions, into everyday practice as a means to influence the systems within which they are embedded. It is not clear, however, to what extent critically reflexive practice can influence transformative outcomes of open development.

\section{Multi-dimensionality}

Open development can have impacts along a series of outcome dimensions that are not always mutually reinforcing or complementary. Much development practice has been plagued by linear managerial approaches characterized by cause and effect thinking (Easterly, 2006; Eyben, 2010; Ramalingam, 2013), open development similarly necessitates a shift to a multi-dimensional approach in order to harness its full potential. Davies and Perini (2016) chronicled how the Open Data for Developing Countries workgroup identified three major outcome avenues. They argued that traditional one dimensional approaches to open data provision were inadequate for sensing and evaluating outcomes to respond to emergent requirements in context across the various outcome avenues. A cyclical approach enabled the workgroup to tackle multiple dimensions iteratively. Alternatively, typologies are another approach to multidimensionality drawn from systems theory, where "typologies can show how behavior of a multidimensional system differs significantly according to the emphasis on one or the other dimension" (Gharajedaghi, 2006, p. 41). For instance, in an open educational resource (OER) sharing system, the production of resources by and for teachers is one dimension that can benefit professional development and pedagogy. Whereas enabling student contributions may alter the system in significantly different ways. A typological 
approach implies that actors can strategically integrate multiple dimensions into a qualitatively new whole.

In sum, there is a need for greater granularity whilst investigating the impact of open development on poor and marginalized populations. Much of the research has focused on individual or project-level gains, without taking into account the power and structural issues at play within societal transformation processes. The open development dimensions outlined above posit that power hierarchies in social contexts will lead to particular approaches and formations of openness. What is then needed is a better understanding of how and whether these conditions lead to transformation for poor and marginalized populations.

\section{Transformation processes}

Having identified dimensions to open development one can then consider how transformation happens. Transformation is connotatively different than the concept of change because it implies the achievement of a noticeable threshold of dramatic change. However, it remains challenging to determine what the thresholds are and who determines them. We propose to distinguish between the form and structure of transformation as a means to clarify these inherent complexities.

Top-down transformation configurations have been proposed by Hanna (2010) and Brown, Fishenden and Thompson (2014). Hanna (2010) argues that nations can take calculated steps to transform all levels of a society and suggests three fundamental roles for the use of ICTs: 1) accessing and sharing information and knowledge; 2) speeding up and reducing transactions costs; and 3) making connections amongst people, communities, enterprises and NGOs. Brown et al. (2014) proposed that digital transformation can be conceptualized as a four-layer business model that responds to the digital innovation landscape. They view digital transformation as a means to revolutionize the way that governments offer efficiency and meet citizens' needs inclusively.

A second form of transformation is bottom-up. Poveda and Roberts (2017) argued that transformation occurs when individuals and collectives develop critical-agency to tackle structural power and the root causes of inequality. Open development must therefore enable "disadvantaged people themselves to excavate the root causes of the (dis)advantage that they experience, determine their own development interests and challenge structural inequalities." Transformation processes in this sense must target disadvantaged people and ensure it is they who determine and identify the transformation threshold.

Top-down and bottom-up forms are differentiated by views on decision-making and objectives of transformation. Hanna (2010) centers on accelerating economic growth and reducing poverty. These objectives can be viewed as inherently problematic as a framework for transformation because economic growth is usually unsustainable (Schmandt, Ward, \& Hastings, 2000), while poverty reduction does not always challenge the root causes of poverty (Unwin, 2007). Poveda and Roberts' (2017) view 
does not resolve this issue but implies that populations can develop capabilities to decide a beneficial future for themselves. However, participatory processes are also vulnerable to deficiencies in effectiveness if collectives do not adequately organize to reach consensus (Cooke \& Kothari, 2001) or gain power to influence structural inequalities (Korten, 1990). Either form of transformation is amenable to both positive transformation or limited effect.

Busken's (2014) structures of transformation are therefore needed to clarify three categories of transformation: 1) conformist: transformation reinforces the status quo; 2) reformist: transformation changes aspects of the situation dramatically but leaves societal structures in tact; and 3) transformative: transformation significantly changes unequal relations and societal structures that support these. Structures of transformation differentiate dramatic change by the consequence it has on the context. Roberts (2016) argued that conformist and reformist types can have value within transformation processes over the long-term because they often establish pre-requisite and essential pre-conditions for transformation to occur.

However, given the distributive nature of development impact, in which there may be many positive and negative outcomes occurring simultaneously, we argue that there is a need to examine transformation processes and outcomes with greater differentiation. We draw on the above forms and structures of transformation processes to examine the impact of open development on different actors and contexts. This enables a more sensitive analytic approach to understand impact for poor and marginalized populations, as these populations are not uniform in nature. This is in contrast to a summative approach seeking to evaluate whether or not a particular initiative had a positive, transformative effect, or as a normative ideal to be attained.

\section{Development outcomes}

Capabilities and accountability are two key development objectives that have gained prominence due to the need for plural and multi-faceted human development approaches (United Nations, 2015). The next two sections outline our approach.

\section{Capability outcomes}

In contrast to development as an economic imperative, Sen (2001) argued that expanding freedom defines development. Human well-being is a function of multiple social, cultural, economic and political dimensions which are not determinant and should not be dictated (Robeyns, 2003). Therefore, development is "a process of expanding the real freedoms that people enjoy" (Sen, 1999, p.3), which "concentrates on the capabilities of people to do things - and the freedom to lead lives - that they have reason to value" (Sen, 1999, p.85). The ability of the individual to pursue her values is known as agency, which enables the individual to act upon the realization of her goals. Capabilities could be increased or constrained by lack of agency, but these are also impacted by social structures and the resources available to the individual (Kleine, 2013; Robeyns, 2005; Sen, 2001). Resources refer to any material, social, economic, or practical aspect that a person can instantiate to meet their objectives. Capabilities as a 
representation of a person's freedom to achieve what she or he values and has reason to value, makes it difficult to pinpoint capability outcomes.

Analyzing development according to multiple dimensions has also weakened the operationalization of the capability approach (CA) (Corbridge, 2002; Devereux, 2001; Robeyns, 2000; Sen, 1999). Sen (1999) chose to leave the CA open in order to enable contextual sensitivity. Other authors have proposed more specific alternatives. For instance Nussbaum (2000) proposed a set of 10 normative capabilities. Other examples of operationalization of the CA in ICT4D specifically come from Kleine (2013), Gigler (2015), Johnstone (2007), Zheng and Walsham (2008), and Oosterlaken (2011). Due to the focus on transformation of the present study, Kleine's (2010) choice framework gives a clear description of how transformation happens from start to finish. In her framework, the concept of agency is represented by all resources available to the individual. These resources are affected by social structures, impacting on their opportunities as well. Resources are instrumental to an individual's choices. The increase or decrease of resources then impacts the individual's agency, her choices and consequently her degree of empowerment and human development.

It is important to clarify that the dictionary definition of capabilities refers to the power or ability of a person to accomplish a specific action. This everyday use, whilst accurate, fails to capture wider structural entanglements that affect a person's power or ability implicit in their actions, assumed in the concept proposed by the capability approach. Zheng and Stahl (2011) argue that agency is shaped by the structures of society and should not be viewed independently. Therefore an analysis that views capabilities as a power or ability independent of societal structures is likely too narrow within a discussion of capability outcomes. We define this everyday use as capacities to make clear the distinction.

In sum, capability outcomes, as an expansion of freedoms, are complex and do not conclusively indicate tangible and easy to measure outcomes. Approaches that analyze a variety of agency, resource and opportunity dimensions, along with interactions between agency and structure seem to be the most equipped to evaluate capability outcomes. These also seem the most pertinent to a discussion of transformation processes.

\section{Accountability outcomes}

Accountability is a term that has different meanings based on purpose and context. In politics, discussions of accountability often revolve around to whom accountability is owed (Oliver, 1991). For organizational contexts, accountability is shaped by legal liability constraints (Bovens, 1998) and sets of practices (J. Roberts, 1991; J. Roberts \& Scapens, 1985). Within development, amidst burgeoning neo-liberal agendas in the 1980s, and solidified by the Paris Declaration in 2005, performance, efficiency, and effectiveness became the focus of accountability discourses (Jordan \& van Tuijl, 2006). In order to clarify accountability outcomes, it is useful to distinguish between its form and purpose. To this end, this paper applies Leat's (1988) three forms of accountability: 1) accountability with sanctions, which denotes legal and fiscal obligations, 2) 
explanatory, which outlines the duty actors have to explain their actions in both formal and informal ways, and 3) responsive, which refers specifically to the duty actors have to respond to, and include stakeholders in their activities when there are no sanctions or formal obligations to do so. Other specific forms, such as democratic accountability (Bendell, 2006; Hanberger, 2009), or mutual accountability (L. D. Brown, 2007; EU, 2010), have also been suggested. However, accountability theory has not yet been thoroughly contextualized to open development. For our purposes, Leat's (1988) three basic forms provide an adequate starting point that enables a general comparison of accountability outcomes within open development literature.

Furthermore it is vital to establish the purpose of accountability to contextualize accountability outcomes. Relatively few studies have investigated accountability outcomes in open development specifically (Bentley \& Chib, 2016; Bentley, 2017). However it seems clear that actors can face multiple accountability demands simultaneously and will frequently have to choose between them. For example, governments need to balance the responsibility they have to fulfill their legislative duties whilst attempting to meet citizen needs when contemplating a process to share government data openly. Similarly, when universities seek to support staff to contribute to OER initiatives, they must also balance the responsibility they have to offer reputable degree programmes with ensuring that resources developed through the initiative are of adequate quality, have the proper open licenses, and help staff respond to the educational needs of the students. Koppell (2005) argued that failing to assert the purpose of accountability leads to multiple accountability disorder, in which actors attempt to pursue all accountability purposes simultaneously and end up doing none of them well, thus interfering with intended accountability outcomes. We investigate the applicability of Koppell's (2005) framework to identify the purpose of accountability in open development. These dimensions are: 1) controllability, which denotes whether the actor did what it was supposed to do (as within principal-agent relationships); 2) liability, which is concerned with facing legal consequences for performance outcomes; 3) transparency, which is about revealing facts about performance; 4) responsibility, which means following rules and fulfilling roles; and 5) responsiveness, which refers to fulfillment of the substantive expectations of stakeholders.

To summarize, our theoretical framework suggests three main aspects key to understanding the impact of open development on poor and marginalized populations (Table 1). First, we put forth seven dimensions of open development to investigate the links between openness, transformation processes and development outcomes. Second, we outlined transformation processes in terms of their form and structure, stressing a need for granularity within existing models which neglect the differential distributed nature of development impact. Third, we put forth two development outcomes, capabilities and accountability, which represent the systemic freedoms and protections of poor and marginalized populations. The following section explains how we operationalized our investigation which concentrates on how and whether different dimensions of open development shed light on transformation processes and development outcomes. 
Table 1: Summary of the theoretical framework to explore links between dimensions of openness, transformation processes and development outcomes

\begin{tabular}{|c|c|c|}
\hline Dimensions & Transformation & Outcomes \\
\hline $\begin{array}{ll}\text { 1. } & \text { Power dynamics } \\
\text { 2. Actors, winners and losers } \\
\text { 3. Conception of technology } \\
\text { 4. Processes of digitally- } \\
\text { 5. } \\
\text { 5. Multed openness } \\
\text { 6. Critical levels of analysis } \\
\text { 7. } & \text { Multi-dimensivity } \\
\end{array}$ & $\begin{array}{l}\text { - Form: } \\
\text { - Top-down } \\
\text { - Bottom-up } \\
\text { - Structure: } \\
\text { - Conformist } \\
\text { - Reformist } \\
\text { - Transformative }\end{array}$ & $\begin{array}{l}\text { - Capability: } \\
\text { - Expansion of freedoms, } \\
\text { agency, choice } \\
\text { - Accountability: } \\
\text { - Controllability } \\
\text { - Liability } \\
\text { - Transparency } \\
\text { - Responsibility } \\
\text { - Responsiveness }\end{array}$ \\
\hline
\end{tabular}

\section{Methods}

We applied a content analysis procedure to a purposeful sample of articles drawn from a database of 269 open development articles within Lower, Lower-Middle and UpperMiddle income countries, as defined by the World Bank (n.d.). These articles were retrieved from the Scopus database and four ICT4D journals, covering the years 2010 to 2015. For further details regarding how these articles were selected and retrieved (Bentley \& Chib, 2016; see Appendix).

\section{Identifying capability and accountability research}

We ran full text searches for "capabilit" to "accountabilit" to find articles. Articles were included if they referenced accountability or capabilities more than once within the theoretical, empirical and/or discussion sections of the article. Articles were excluded if they did not engage substantively with capability or accountability outcomes. We included articles that referenced human-related capabilities, and excluded articles that referred to technology capabilities only. We excluded private sector firm capability outcomes. Additional data are needed to analyze links between social transformation processes and private sector capability outcomes. We suggest to pursue this line of research in a standalone study.

A more tenuous decision was made to exclude studies that did not provide sufficient detail of empirical data and outcomes of initiatives. We therefore excluded tools, practice and design models that were not empirically confirmed. We accepted qualitative, quantitative and mixed studies. Self-reported interview studies were included if they explained or engaged with existing initiatives. Studies that sought to 
document motivations and barriers of stakeholders prior to implementation were excluded.

\section{Analyzing transformation processes of open development}

A scheme was developed based on our theoretical framework for the content analysis (Bryman, 2008). Bernard (2013) suggested that hypothesis coding enables researchers to build explanatory models from existing texts by performing a content analysis that tests hypotheses. As opposed to an exploratory model concerned with uncovering hypotheses from texts, Saldana (2009) argues that hypothesis coding is appropriate to use when looking for rules, causes and explanations in data. Based on the theoretical framework, we developed a list of codes to represent hypotheses we had concerning each open development dimension. For example, regarding the structures of openness, DETAILED was used when we deemed the article to articulate digitally enabled openness extensively, but LIMITED was used when little information regarding what openness meant was provided. Codes were also applied to identify transformation and outcome categories. All articles were coded and analyzed using nVivo qualitative analysis software. Memos were attached to articles to document reflections. These documented reasons for judgements and enabled a holistic and critical examination of literature (Charmaz, 2006).

\section{Findings}

We outline the outcome results first because they demonstrate the type and quality of outcomes. Transformation forms are then presented. We then focus on the links between open development dimensions, transformation processes and outcomes. The open development dimensions of the articles are threaded throughout the results sections. The papers are selected as representative of the coded themes, and do not quantitatively signify patterns.

\section{Outcomes}

The primary categories of capability and accountability outcomes are outlined in Table 2. Although most studies had multiple outcomes, we chose to display the primary category to give the reader a general sense of the article's main focus. Open development initiatives often have mixed, ambiguous, or none of the intended outcomes. For capability outcomes, this finding is reflected by increases in resources, without accounting for choice or agency. For instance, Handlykken's (2012) expert informants suggested that South African open source policy was meant to establish common good resources, but that these resources did not materialize advantageously for people that needed them the most. Likewise, Hatakka and Lagsten's (2012) study explored how developing country students at a Swedish university benefitted from Internet resources. They argued that some students will choose to use Internet resources to lead to transformative capability outcomes, whilst others will not. Their analysis identified conversion factors that outline a range of pathways to capability outcomes in 
personal, educational and professional areas of their lives. This was the only study to apply a CA approach, most other studies did not engage actively with the capability approach and its unique way of conceptualizing capabilities. Consequently, most studies focused incorrectly on resource provision as an indicator for capability expansion. While an improvement of resources is a benefit, according to the capability approach, it is not enough to expand capabilities.

Table 2: General overview of topics and outcomes identified within the literature review and categorized according to our theoretical framework

\begin{tabular}{|c|c|c|c|c|}
\hline & Capabilities & Topic & Accountability & Topic \\
\hline Positive & $\begin{array}{l}\text { (3) Resources: Ansal \& } \\
\text { Yildirim (2010), } \\
\text { Rangaswamy \& Nair, } \\
\text { (2011), van der Boor, } \\
\text { Oliveira, \& Veloso } \\
\text { (2014). } \\
\text { (1) Structure-agency } \\
\text { interplay: Hoque \& } \\
\text { Sorwar (2015). }\end{array}$ & $\begin{array}{l}\text { - Open source } \\
\text { developer } \\
\text { community } \\
\text { - Tele-centres } \\
\text { - mobile phone } \\
\text { innovation platforms } \\
\text { - Technology service } \\
\text { entrepreneurship }\end{array}$ & $\begin{array}{l}\text { (2) Controllability: } \\
\text { Eros, Mehndiratta, \& } \\
\text { Zegras (2014), Tom-Aba } \\
\text { et al. (2015). } \\
\text { (1) Responsibility: } \\
\text { Iyengar et al. (2015). }\end{array}$ & $\begin{array}{l}\text { - Ebola virus } \\
\text { management } \\
\text { - Transport data } \\
\text { standard } \\
\text { - Education } \\
\text { planning and } \\
\text { decision- } \\
\text { making }\end{array}$ \\
\hline $\begin{array}{l}\text { Mixed, } \\
\text { neutral, } \\
\text { or none }\end{array}$ & $\begin{array}{l}\text { (1) Resources: } \\
\text { Handlykken (2012), } \\
\text { Hatakka \& Lagsten } \\
\text { (2012) } \\
\text { (1) Capacities: } \\
\text { Williams, Marcello, \& } \\
\text { Klopp (2013) } \\
\text { (1) Information: } \\
\text { capabilities Meesters \& } \\
\text { Van de Walle (2013) }\end{array}$ & $\begin{array}{l}\text { - Open source } \\
\text { software policy } \\
\text { - Use of Internet } \\
\text { resources in } \\
\text { education } \\
\text { - GIS information } \\
\text { provision } \\
\text { - Volunteer } \\
\text { information } \\
\text { production }\end{array}$ & $\begin{array}{l}\text { (3) Responsiveness: } \\
\text { Ohemeng \& Ofosu- } \\
\text { Adarkwa (2015), } \\
\text { Sadoway \& Shekhar, } \\
\text { (2014), Williams et al. } \\
\text { (2013) } \\
\text { (6) Transparency: } \\
\text { Canares (2014), } \\
\text { Chattapadhyay (2014), } \\
\text { Murillo (2015), B. } \\
\text { Raman (2012a), N. V. } \\
\text { Raman (2012b) } \\
\text { (1) Responsibility: van } \\
\text { Schalkwyk, Willmers, \& } \\
\text { McNaughton (2015) } \\
\text { (1) Liability: Vidolov } \\
\text { (2014) }\end{array}$ & $\begin{array}{l}\text { - Urban planning } \\
\text { - Open } \\
\text { government } \\
\text { data initiatives } \\
\text { - University } \\
\text { governance } \\
\text { - Volunteer } \\
\text { information } \\
\text { production }\end{array}$ \\
\hline
\end{tabular}

Accountability outcomes were not usually determined based on theory or a systematic procedure. However similar findings were apparent within transparency studies. Transparency takes an explanatory form of accountability because actors share facts about their actions. Authors debated the validity of this accountability purpose because shared information did not represent the facts. N.V. Raman (2012b) and B. Raman (2012a) both highlighted problems with India's Right to information (RTI) policy, when marginalized groups attempted to retrieve land or public toilet records. Officials withheld, provided inconsistent, or did not have, the correct information. Moreover, Chattapadhyay (2014) argued that intermediaries are needed to synthesize and 
aggregate data to enable this information to be used by citizens. These findings were mirrored in other contexts by Murillo (2015) and Canares (2014) who both argued that public information distribution should support a responsive form of accountability rather than an explanatory form. Moreover, Michener (2015) examined international transparency composite indexes, concluding that these "seem to have become a monolithic measurement 'strategy' due to their ability to captivate public interest. They are fine public relations tools and serve well when what is being measured is substitutable." Equating transparency to a public relations tool indicates a significant level of skepticism that responsive forms of accountability will transpire through volition.

Three articles explored responsiveness outcomes specifically. Ohemeng and OfosuAdarkwa (2015) positioned their analysis of the Ghanaian open government data initiative on demand-side deficiencies. However, it is not clear if responsive forms exist in Ghanaian government, or just not in this initiative. Two other articles identified government failure to accommodate citizen needs and developed civil society-led responsive processes. Whilst these initiatives showed promising outcomes, civil society organizations often have reputations as responsive actors (notwithstanding critique (Howell \& Pearce, 2001; Van Rooy, 2009)), so these outcomes do not necessarily indicate dramatic change. Positive outcomes reported for healthcare and educational institutions were also demonstrative of this quality (Table 2). Controllability and responsibility gains are still accountability outcomes, but perhaps indicate limits to the structure of transformation that is sought.

\section{Transformation processes}

Current evidence portrays an abundance of top-down strategies (Table 3), contrary to open development rhetoric that places a high-emphasis on self-organized and decentralized processes. Open initiatives began through policy creation, planning, and strategic management led by traditional development institutions like governments, donors and civil society organizations. This fits within the role of governments to institute policy and planning to increase accountability to, and expand capabilities of, its citizens. However top down strategies were also used outside of government or as a result of government policy intervention. Furthermore many these studies mentioned that originators of initiatives maintained significant oversight.

Table 3: Studies grouped by transformation forms and development outcome

\begin{tabular}{|l|l|l|}
\hline & Capabilities & Accountability \\
\hline Top-down & (1) Hoque \& Sorwar (2015) & $\begin{array}{l}\text { (5) Canares (2014), Iyengar et al. (2015) } \\
\text { Michener (2015), Ohemeng \& Ofosu-Adarkwa } \\
\text { (2015), Tom-Aba et al. (2015) }\end{array}$ \\
\hline Bottom-up & $\begin{array}{l}\text { (3) Hatakka \& Lagsten (2012), Rangaswamy } \\
\text { \& Nair (2011), Williams et al. (2013) }\end{array}$ & $\begin{array}{l}\text { (1) Sadoway \& Shekhar (2014), Williams et } \\
\text { al. (2013) }\end{array}$ \\
\hline
\end{tabular}




\begin{tabular}{|l|l|l|}
\hline Dialectic & (3) Ansal \& Yildirim (2010), Meesters \& Van & (7) Chattapadhyay (2014), Eros et al. (2014), \\
de Walle (2013), van der Boor et al. (2014) & $\begin{array}{l}\text { Murillo (2015), B. Raman (2012a) N. V. Raman } \\
\text { (2012b), van Schalkwyk et al. (2015), Vidolov } \\
\text { (2014) }\end{array}$ \\
& & \\
\hline
\end{tabular}

Top down forms were often apparent in government initiatives to open or enable access to information. Authors identified serious problems with a purely top down approach, arguing that governments failed to conceptualize and enact appropriate strategies to enable citizen participation (Canares, 2014; Murillo, 2015). However bottom-up forms of transformation were also problematic. Alternative initiatives, such as Williams et al.'s (2013) initiative to create GIS information in Kenya, were created from the bottom-up because governments refused to open requested information up but later encountered maintenance issues. This means that a bottom-up form was enacted but likely have little impact on the structure of transformation because the initiative would not be sustained.

We identified a third form of transformation within the research. A dialectic form is needed to describe interactions between the top-down and bottom-up forms. Top-down policy instigated actors to respond in ways laid out by high-level actors at times. For instance, Eros et al.'s (2014) explored a transport data standard that the Mexican government instituted to encourage private sector actors to build apps and services for citizens. Then, issues like vague stop locations or variable distances incurred workarounds to fit the standard to the context. Both top-down and bottom-up forms melded together dialectically. In contrast, three Indian case studies were contesting the government, rather than contributing, in response to top-down transformation. Dialectic forms seem to address problems identified by authors critiquing purely top-down or bottom-up strategies, indicating that both are needed in open development.

Moreover, the findings indicate that structures of transformation within open development are likely shaped by wider societal conditions. In other words, it is often outside of the realm of the initiative - due to neglect of dimensions or actors, or a lack of power or position - to achieve transformative outcomes. Nevertheless reform was easily apparent across many studies. The kinds of reform were diverse and affected institutional structures, decision-making, efficiency and effectiveness procedures, resource allocation, and citizen rights. However these findings are better understood in context and are thus discussed next.

\section{Links between open development dimensions, transformation processes and outcomes}

This section groups the studies according to similarities in the ways that specific dimensions enable analysing for the positive, or mixed outcome effects. These groups theorize how transformation occurs in open development thus far. They outline that the dimensions and transformation processes primarily do not lead to transformative 
outcomes as it stands. The groups are summarized in Table 4 as follows: 1) Embedded reform: studies reporting positive outcomes and significant institutional or process reform. These reforms were contained within a sub-system and did not significantly alter the status quo. 2) Constructing reform: studies that identified specific reforms and argued for additional strategies or resources to achieve transformative outcomes. 3) Contesting reform: these studies outlined similar responses to systemic failure as a means to work towards reform. 4) Conforming: similar dimensions also explained lack of transformative outcomes. 
Table 4: Groups of research according to transformation processes and outcomes

\begin{tabular}{|c|c|c|c|}
\hline $\begin{array}{l}\text { Description of } \\
\text { transformation process }\end{array}$ & Type of outcome & $\begin{array}{l}\text { Dimensions of open } \\
\text { development used }\end{array}$ & Strengths and weaknesses \\
\hline \multicolumn{4}{|c|}{ Group 1: Embedded reform (6) } \\
\hline $\begin{array}{l}\text { Mix of top-down, bottom- } \\
\text { up and dialectic } \\
\text { transformation forms that } \\
\text { significantly change the } \\
\text { context, but do not } \\
\text { challenge existing societal } \\
\text { structures, or seek to do } \\
\text { so. }\end{array}$ & $\begin{array}{l}\text { Positive outcomes. } \\
\text { Significant positive } \\
\text { changes in knowledge } \\
\text { sharing, efficiency, and } \\
\text { institutional structures, } \\
\text { leading to improvements } \\
\text { in public services and } \\
\text { protection (health). }\end{array}$ & $\begin{array}{ll}\text { - } & \text { Social-embedded } \\
& \text { conception of } \\
\text { technology } \\
\text { - } & \text { Structures of } \\
& \text { openness } \\
-\quad & \text { Multiple levels of } \\
\text { - } & \text { analysis } \\
\text { Multi-dimensionality }\end{array}$ & $\begin{array}{l}\text { Strength } \\
-\quad \text { Effective for granular } \\
\text { analysis of specific } \\
\text { structures of } \\
\text { openness. } \\
\text { Weakness } \\
-\quad \text { Unable to explain } \\
\quad \text { structure of } \\
\quad \text { transformation. }\end{array}$ \\
\hline \multicolumn{4}{|c|}{ Group 2: Constructing reform (5) } \\
\hline $\begin{array}{l}\text { Top-down strategies spur } \\
\text { constructive responses } \\
\text { from stakeholders. } \\
\text { Authors analyse } \\
\text { additional factors and } \\
\text { considerations to further } \\
\text { improve initiatives, with } \\
\text { some arguing that } \\
\text { transformative outcomes } \\
\text { are possible in the future. }\end{array}$ & $\begin{array}{l}\text { Mixed or neutral } \\
\text { outcomes. Some actors } \\
\text { and institutions } \\
\text { demonstrate positive } \\
\text { capability or } \\
\text { accountability outcomes, } \\
\text { but problems are } \\
\text { identified. }\end{array}$ & $\begin{array}{ll}\text { - } & \text { Multi-dimensionality } \\
\text { - } & \text { Social-embedded } \\
\text { conception of } \\
\text { technology } \\
\text { - } & \text { Multiple levels of } \\
\text { - } & \text { analysis } \\
\text { - } & \text { Actor dynamics } \\
\text { - } & \text { Structures of } \\
\text { openness }\end{array}$ & 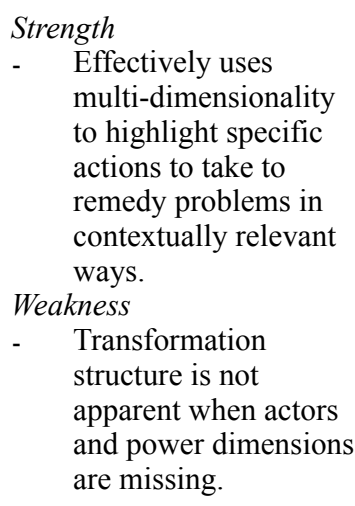 \\
\hline \multicolumn{4}{|c|}{ Group 3: Contesting reform (4) } \\
\hline $\begin{array}{l}\text { Top-down strategies spur } \\
\text { contesting responses, or } \\
\text { bottom-up strategies arise } \\
\text { to address unmet needs as } \\
\text { a means to contest } \\
\text { systemic failure. }\end{array}$ & $\begin{array}{l}\text { Mixed or neutral } \\
\text { outcomes. Some actors } \\
\text { might gain skills through } \\
\text { participation to contest or } \\
\text { collaborate, but they may } \\
\text { also be negatively } \\
\text { impacted if initiatives do } \\
\text { not ultimately serve their } \\
\text { interests. }\end{array}$ & $\begin{array}{ll}- & \text { Power dynamics } \\
- & \text { Actors } \\
- & \text { Social-embedded } \\
& \text { conception of } \\
\text { technology } \\
\text { - } & \text { Structures of } \\
\text { openness }\end{array}$ & $\begin{array}{l}\text { Strength } \\
-\quad \text { Effective involvement } \\
\text { of marginalized } \\
\text { people and social- } \\
\text { embedded approach } \\
\text { Weakness } \\
-\quad \text { Limited to a granular } \\
\text { analysis }\end{array}$ \\
\hline \multicolumn{4}{|l|}{ Group 4: Conforming (4) } \\
\hline $\begin{array}{l}\text { Top-down forms of } \\
\text { transformation that do not } \\
\text { incur significant } \\
\text { responses. }\end{array}$ & $\begin{array}{l}\text { Mixed outcomes. Uncover } \\
\text { similar outcomes as } \\
\text { Group 3, but have not } \\
\text { supported related skill } \\
\text { gains through citizen } \\
\text { participation in initiatives. }\end{array}$ & $\begin{array}{ll}- & \text { Multi-dimensionality } \\
- & \text { Multiple levels of } \\
\text { - } & \text { analysis } \\
\text { - } & \text { Actors } \\
& \text { Social-embedded } \\
\text { conception of } \\
\text { technology } \\
-\quad \text { Structures of } \\
\text { openness }\end{array}$ & $\begin{array}{l}\text { Strength } \\
-\quad \text { Effective use of multi- } \\
\text { dimensionality and } \\
\text { multiple levels of } \\
\text { analysis } \\
\text { Weakness } \\
-\quad \text { Critical reflexivity }\end{array}$ \\
\hline
\end{tabular}

\section{Group 1: Embedded reform}

Six studies reported positive outcomes and demonstrated reformist transformation. We label these as embedded reform because reform is contained within an existing suprastructure. These studies focused on open structures as a main causal factor. Four of the studies did not engage with an analysis of power or examine poor and marginalized 
populations, which was not viewed as necessary. Technical approaches, or a singular level of analysis, explain three of these four. For example, Tom-Aba et al. (2015) showed that Ebola treatment was managed significantly better after a technical intervention, because it enabled the institution to carefully monitor activity protocol, thus contributing positively to the controllability purpose of accountability. Whereas Ansal and Yildirim's (2010) study is emblematic of a complex case but that implemented a singular level of analysis. They argued that the Linux open source developer community in Turkey contributed positively to the creation of social and human resources that both developers and businesses benefit from, thus expanding capabilities. However there is no analysis of power or marginalisation within the developer community itself because the analytic focus relates to the contribution of the community to Turkey's competitiveness in the global software sector.

In contrast, Rangaswamy (2011) and Van der Boor's (2014) studies focused on poor and marginalized populations specifically, arguing that openness enabled these populations to innovate on their own behalf, thus expanding capabilities. Neither of these studies articulated structures of openness in much detail; for example, Van der Boor (2014) used the term "platform openness" but seemed to mean the constitutive entanglement of the technology infrastructure in practice. However a CA perspective would focus on a deeper analysis of agency and choice to reach conclusions. Positive results should therefore be interpreted with caution, indicating that power dynamics, analytic levels and multi-dimensionality are vital to evaluate these outcomes.

\section{Group 2: Constructing reform}

Five studies identified significant reform in certain aspects of an open initiative but that these reforms were inconsequential to the lives of marginalized people. Open development dimensions were used to explain how to constructively contribute to transformation processes in this case. Only some of these addressed marginalized perspectives directly. Canares (2014) compared perspectives of the full range of actors within the Philippines local governance sphere. He argued that a multi-dimensional approach to engage citizens online and offline, including listening to their needs and building awareness, was needed alongside high-level reform and adjustment to continually improve open data processes and sharing. Alternatively, Van Schalwyk (2015) applied an ecosystems approach to outline how interactions between dimensions, actors, structures of openness and power dynamics created vicious cycles within the ecosystem. Vicious cycles were an effective way to explain contradictions arising from competing interests of actors who control sources and provision of data. These significantly affected accountability outcomes and implied a need for multiple levels of analysis.

Vidolov (2014) and Meesters and Van de Walle (2013) both explored volunteer peer production networks that contribute to disaster response. Networks collaborated with reputable organisations, and the articles investigated collaboration processes. These initiatives did not target marginalized populations directly, rather serving marginalized populations if crises arose. As such, Vidolov's (2014) analysis of power and control lacks potential to explain transformation. Whilst he identified significant reform in 
practice models, and accountability outcomes related to the volunteer networks, additional dimensions are needed to establish whether transformative outcomes are achievable, such as the actors dimension.

\section{Group 3: Contesting reform}

Four studies centred on contesting reform in public information sharing by powerful actors. All four studies signified the importance of social-embedded conceptions of technology, and that structures of openness are negotiated in context. N.V. Raman (2012) and B. Raman (2012) mainly applied the actors and power dynamics dimensions to show that transparency of information required contextualisation to the political circumstances, and that marginalized groups had limited power to hold government officials to account. Sadoway and Swain (2014) compared top-down and bottom-up approaches to enact ICT-enabled urban planning in Chennai, arguing that the latter led to more valuable reform because of combined face-to-face and participatory ICT engagement. Participatory processes were more appropriate to deal with local development needs responsively. Williams et al. (2013) was the only study in this group that did not engage marginalized groups directly. The researchers' contesting response was to build their own dataset to share publicly new resources, which solidified their local partnerships. However they acknowledged that they should have involved these partners actively from the start so as to encourage these groups to assume more responsibility, and to identify relevant uses of this information. This was one of the only studies that wrote from a critically reflexive standpoint.

\section{Group 4: Conforming}

Open development dimensions provide explanatory value to why transformation failed to materialize. Multi-dimensionality was both applied and emerged through analysis in all of the four studies of this group. Handlykken's (2012) interviews identified issues surrounding the capacity and allocated resources of the government, a flawed procurement process that did not enforce the policy, and complementary policies that led to contradictory effects. Whereas Ohemeng and Ofosu-Adarkwa (2015) took a 10dimensional splice of the Ghanaian open data initiative, examining why the demandside was not responsive. Their concluding view, however, still centred on lack of toplevel legislative reform and lack of resources that are needed to spur demand-side transformation. In other words, they used a multiple level analysis to draw attention to the need to pursue a dialectic form of transformation. Furthermore Murillo (2015) used principal-agent theory to argue Latin American governments systematically used transparency practices to maintain an asymmetrical position that reinforces their own structures and policies and that exploits the laws to hide facts by leaving information unprocessed or by overloading citizens with irrelevant information.

\section{Discussion: How do the dimensions shed light on transformation processes and outcomes of development?}

The above analysis demonstrates that there are many open development models which enable transformation processes and outcomes at different scales and levels of 
complexity. Each actor has their own philosophy regarding how digitally-enabled openness contributes to positive social transformation. The research we reviewed shares certain common denominators, and these are outlined in this section. Open development is referred to singularly in this section to simplify matters for the reader.

The central theme of the literature was that the types and processes of openness identified typically fell into Smith and Seward's (2017) three praxis categories. This is helpful because, as they remarked, openness is notoriously vague, and its fluid boundaries and socially-embedded constructions can cause much confusion. Judging by the wide variety of initiatives undertaken, "open development" encompasses everything from lifelong learning and urban infrastructure to disease outbreak management and national policy formation. This tremendous diversity causes some authors to question the relevance of theorising a generalized approach to open development (Buskens, 2013; Gurstein, 2010b).

However it is vital to examine open development across multiple dimensions. Taken on a singular case-by-case basis, most open development initiatives appear to start out unambiguously positive. Who can oppose the principles of non-discriminatory, free, and low barriers to entry that underpin open processes? The difficulty with examining open development only in terms of processes, or by project, an approach characteristic of most of the studies examined, is that it tends to prevent a sober examination of the historical and political context of the initiatives. Moreover a process or project approach precludes an understanding of the societal structures within which processes unfold, or of the multiplier effects inherent to interacting open processes. With such a narrow focus, most open development literature lacks purview to identify and explain transformative outcomes.

Two main findings shed light on how numerous dimensions of open development increased the potential to explain transformative outcomes significantly when: 1) authors focused on the power and actor dimensions of open initiatives; and 2) authors contextualized systemic aspects through multi-dimensionality or multiple levels of analysis.

\section{Focusing on the power and actor dimensions of open development initiatives}

Two essential dimensions of open development are the actors and power dynamics dimensions. Decisions about whose perspectives to prioritize, how to allocate resources, or whose interests to serve determine the ensuing events that unfold within open processes. Open social praxis become dominant not because it works in some abstract sense, but because it works for specific people and institutions. However the majority of studies did not engage marginalized people in their research directly. In this case, explanatory potential is limited to defining boundaries that outline transformation processes and outcomes rather than specific pathways to outcomes. For example, Canares (2014) and Handlykken (2012) both outlined how governmental practices influenced the opportunities citizens had to take advantage of open government data and open source software respectively instead of focusing on citizens in pursuit of their own interests. 
Moreover studies that did engage marginalized people directly still lacked purview of wider power structures or had difficulty contesting powerful actors. This indicates that the actor and power dimensions are at times supplemented by multi-dimensionality and multiple level analysis to increase explanatory potential. Additionally, there is a need to improve implemented power analysis techniques to increase the effectiveness of this dimension. Many of the potential benefits outlined by Thompson (2008) have not been adequately explored in the context of open development. Power analysis techniques should not focus only on relational inequalities. We recommend a greater emphasis on dynamics of power, which can also analyse production of power, or power across contexts, which are needed to investigate non-determinant and distributed open development environments. Open processes enable different pathways to transformation, and this implies distinct distributions of outcome costs and benefits.

\section{Contextualising systemic aspects through multi-dimensionality or multiple levels of analysis}

Multi-dimensionality and multiple levels of analysis likewise added significant insight, particularly when examining the form and structure of transformation. However we argue that these dimensions are advisable but not essential to explain transformative outcomes. These dimensions were frequently used to argue in favour of marginalized perspectives. However without situating initiatives within wider social and political circumstances authors were unable to explain the structure of transformation. Most researchers implemented either a high-level analysis or a granular analysis but not both. On the one hand, it might not be feasible to accomplish multiple levels of analysis within a single study. On the other hand, it may be necessary to revise methodological approaches based on our understanding that open development transformation forms are typically dialectical and require multiple avenues of investigation, perhaps crossreferencing each other.

Multi-dimensionality and multiple levels of analysis may also provide alternative ways to think about open development systemically. An inclusive theory that unites multidimensionality and multiple levels of analysis is complexity theory, which is increasingly evident in present day IS (Benbya \& McKelvey, 2006; Merali \& McKelvey, 2006) and development theory (Chambers, 2015; Ramalingam, 2013; Rihani, 2002). However theories of self-organisation originated in the late 1950s (Foerster, 2003). There has been a recent impetus to apply evolutionary systems concepts like dynamics, inter-relationships, and self-organisation to development practice. This trend attempts to break dominant practices founded on overly mechanistic, linear, deterministic cause and effect thinking (Ramalingam, 2013). In contrast, most studies examined acknowledge the complexity of open initiatives, and the potential for open processes to drastically expand possibilities of participation, access and collaboration. However modern philosophies of emergence do not mean that just about anything that can possibly happen, will happen (Hofkirchner, 2010). It just means that researchers and practitioners need not attempt to describe and influence outcomes in a mechanistic way. It means thinking about transformation in flexible heterogenous causal patterns that fall within a distinct set of possibilities. A key takeaway from complexity thinking is that influencing transformation can be thought of as any event 
which triggers an open process (Hofkirchner, 2010). Moreover since open social praxis is dependent on its context, outcomes can also be conceptualized as an event encapsulated by a set of circumstances. Hatakka and Lagsten's (2012) study best illustrates this point, as it shows that student use (and non-use) of Internet resources falls into a spectrum of capability outcomes that are flexibly aligned to a set of circumstances.

The critical reflexivity dimension was not easily identified through our content analysis methodology, as this dimension was not apparent in the write-up of the majority of the studies. However, in accordance with Eyben (2014), we argue that this dimension is essential to all development research and practice. Our research shows that there is still a need to interrogate outcomes of open development, particularly capability outcomes, and how actors enact openness to achieve transformative outcomes. Obviously it is not necessary that all researchers and practitioners from multi-disciplines pursue this line of research, but it is possible for all researchers and practitioners to question their contributions towards transformative aims.

\section{Conclusion}

New opportunities to share, produce, and use information and communication resources have professed potential to incur transformative development outcomes. In this study, we reviewed articles that engaged with capability and accountability outcomes of open development to evaluate this claim. However open development, transformation and development outcomes are problematic to define, let alone predict with precise accuracy how open development leads to transformative outcomes. We adopted a theoretical framework that outlined seven cross-cutting dimensions of open development as a means to clarify the contours of open development. We then outlined our approach to transformation and two key development outcomes - capabilities and accountability. This enabled us to analyse a purposeful sample of open development literature effectively to shed light on the composition of transformation processes and outcomes. We also focused on establishing links between open development dimensions and these processes and outcomes.

Our findings indicated a range of positive and mixed outcomes and three forms of transformation processes - top-down, bottom-up and dialectical. At this point, out of the 267 articles originally reviewed, only 21 adequately engaged with capability and accountability outcomes to be included in this study. We did not find convincing evidence of radical transformation amongst the subset, even though our procedure was designed to target substantial outcome evidence. Nevertheless our findings shed light on the characteristics of transformation processes within the field of open development. Our typology of open development reform - embedded, constructing, and contesting are a means to capture the power dynamics of open processes and outcomes. However there is still a need to contemplate how open development researchers can influence transformative outcomes under these circumstances.

The present study concentrated on a deep analysis of literature to outline the dimensions of open development that shed light on transformative development outcomes. However 
our findings may be of interest to Community Informatics (CI) researchers more widely. At the heart of $\mathrm{CI}$ is the assumption that diverse actors must come together to engage and empower communities at multiple levels of practice, policy and governance. Usually, communities do not have homogeneous characteristics or objectives and CI researchers and practitioners must learn to support the use of ICT for expanding human capabilities and to strengthen accountability within communities. Our dimensions may apply to other CI contexts that do not apply openness specifically, but that may be helpful to sort through ambiguous and complex aspects of how ICTs supports positive social transformation within communities. It may also help researchers to conceptualize or target how local community initiatives may impact on structural aspects of society, and vice versa. We suggest that future research implements these dimensions to test and refine them.

\section{Acknowledgements}

This research was conducted as part of the Singapore Internet Research Centre's SIRCA III programme and is funded by the International Development Research Centre (IDRC) of Canada.

\section{References}

Ansal, H., \& Yildirim, N. (2010). Benefiting innovative capabilities of software developer/user communities in developing countries (pp. 1-12). Presented at the Technology Management for Global Economic Growth PICMET, Proceedings of PICMET, Phuket: IEEE.

Avgerou, C. (2001). The significance of context in information systems and organisational change. Information Systems Journal, 11(1), 43-63. http://doi.org/10.1046/j. 1365-2575.2001.00095.x

Avgerou, C., Ciborra, C., \& Land, F. (Eds.). (2004). The social study of information and communication technology: Innovation, actors, and contexts. Oxford: Oxford University Press.

Benbya, H., \& McKelvey, B. (2006). Toward a complexity theory of information systems development. Information Technology \& People, 19(1), 12-34. http://doi.org/ $10.1108 / 09593840610649952$

Bendell, J. (2006). Debating NGO accountability. New York and Geneva: United Nations Publications.

Bentley, C. M. (2017). An analysis of accountability concepts for open development. In Choudrie J., Islam M., Wahid F., Bass J., Priyatma J. (Eds.) Information and communication technologies for development. ICT4D 2017. IFIP advances in information and communication technology, vol 504 (pp. 793-802). London: Springer, Cham.

Bentley, C. M., \& Chib, A. (2016). The impact of open development initiatives in lower- and middle-income countries: A review of the literature. Electronic Journal of Information Systems in Developing Countries, 74(6), 1-20.

Berdou, E. (2011). Mediating voices and communicating realities: Using information crowdsourcing tools, open data initiatives and digital media to support and protect the vulnerable and marginalised. Sussex: Institute of Development Studies. 
Bernard, H. R. (2013). Social research methods: qualitative and quantitative approaches (2nd ed.). London: Sage.

Bovens, M. (1998). The quest for responsibility: Accountability and citizenship in complex organisations (theories of institutional design). Cambridge: Cambridge University Press.

Brito, K. D. S., Costa, M. A. D. S., Garcia, V. C., \& Meira, S. R. de L. (2014). Brazilian government open data: Implementation, challenges, and potential opportunities (pp. 1116). Presented at the The 15th Annual International Conference on Digital Government, Aguascalientes: ACM Press. http://doi.org/10.1145/2612733.2612770

Brown, A., Fishenden, J., \& Thompson, M. (2014). Digitizing government: Understanding and implementing new digital business models. New York: Palgrave Macmillan.

Brown, L. D. (2007). Multiparty social action and mutual accountability. In A. Ebrahim \& E. Weisband (Eds.), Global Accountabilities (pp. 88-111). Cambridge: Cambridge University Press.

Bryman, A. (2008). Social research methods. Oxford: Oxford University Press.

Buskens, I. (2011). The importance of intent: Reflecting on open development for women's empowerment. Information Technologies \& International Development, 7(1), 71-76.

Buskens, I. (2013). Open development is a freedom song: Revealing intent and freeing power. In M. L. Smith \& K. M. A. Reilly (Eds.), Open Development: Networked Innovations in International Development (pp. 327-352). Ottawa: The MIT Press and International Development Research Centre.

Buskens, I. (2014). Developing the capacity for gender awareness in development research: A thinkpiece for IDRC (Unpublished Manuscript).

Canares, M. P. (2014). Opening the local: Full disclosure policy and its impact on local governments in the Philippines (pp. 89-98). Presented at the ICEGOVE 2014, Guimaraes: ACM Press. http://doi.org/10.1145/2691195.2691214

Chambers, R. (2015). Inclusive rigour for complexity. Journal of Development Effectiveness, 7(3), 327-335. http://doi.org/10.1080/19439342.2015.1068356

Charmaz, K. (2006). Constructing grounded theory: A practical guide through qualitative analysis (introducing qualitative methods series). London: Sage Publications Ltd.

Chattapadhyay, S. (2014). Access and use of government data by research and advocacy organisations in India (pp. 361-364). Presented at the ICEGOVE 2014, Guimaraes: ACM Press. http://doi.org/10.1145/2691195.2691262

Cooke, B., \& Kothari, U. (Eds.). (2001). Participation: The new tyranny? London: Zed Books.

Davies, T., \& Edwards, D. (2012). Emerging implications of open and linked data for knowledge sharing in development. IDS Bulletin, 43(5), 117-127. http://doi.org/10.1111/j. 1759-5436.2012.00372.x

Davies, T., \& Perini, F. (2016). Researching the emerging impacts of open data: Revisiting the ODDC conceptual framework. The Journal of Community Informatics.

Easterly, W. (2006). The white man's burden: Why the West's efforts to aid the rest have done so much ill and so little good. New York: Penguin Press.

Eros, E., Mehndiratta, S., \& Zegras, C. (2014). Applying the general transit feed specification to 
the Global South: experiences in Mexico City, Mexico — and beyond. Transportation Research Record: Journal of the Transportation Research Board, 2442, 44-52.

EU. (2010). Mutual accountability and transparency: A fourth chapter for the eu operational framework on aid effectiveness. Brussels: European Union.

Eyben, R. (2010). Hiding relations: The irony of “effective aid.” European Journal of Development Research, 22(3), 382-397.

Eyben, R. (2014). International aid and the making of a better world: Reflexive practice (rethinking development). Abingdon: Routledge.

Foerster, Von, H. (2003). Understanding understanding: Essays on cybernetics and cognition. New York: Springer.

Forte, A., \& Lampe, C. (2013). Defining, understanding, and supporting open collaboration: lessons from the literature. American Behavioral Scientist, 57(5), 535-547. http://doi.org/ $10.1177 / 0002764212469362$

Gharajedaghi, J. (2006). Systems thinking: Managing chaos and complexity. Oxford: Elsevier, Inc.

Gigler, B.-S. (2015). Development as freedom in a digital age: Experiences of the rural poor in Bolivia. Washington DC: World Bank Group.

Gigler, B.-S., Custer, S., Bailur, S., Dodds, E., \& Asad, S. (2014). Closing the feedback loop: Can technology amplify citizen voices? (B.-S. Gigler \& S. Bailur, Eds.). Washington DC: World Bank.

González, J. C., Garcia, J., Cortés, F., \& Carpy, D. (2014). Government 2.0 (pp. 124-136). Presented at the The 15th Annual International Conference on Digital Government, New York, New York, USA: ACM Press. http://doi.org/10.1145/2612733.2612742

Gurstein, M. (2010a). Open data: Empowering the empowered or effective data use for everyone? Retrieved December 22, 2017, from http://gurstein.wordpress.com/2010/09/02/ open-data-empowering-the-empowered-or-effective-data-use-for-everyone/

Gurstein, M. (2010b). The IDRC and "Open Development": ICT4D by and for the new middle class. Retrieved December 22, 2017, from http://gurstein.wordpress.com/2010/12/01/theidrc-and- $\% \mathrm{E} 2 \% 80 \% 9$ Copen-development $\% \mathrm{E} 2 \% 80 \% 9 \mathrm{D}$-ict4d-by-and-for-the-new-middleclass/

Gurstein, M. (2012). Two worlds of open government data: Getting the lowdown on public toilets in Chennai and other matters. The Journal of Community Informatics, 8(2).

Gurumurthy, A., \& Singh, P. J. (2016). Open development - a focus on organisational norms and power redistribution. Retrieved December 22, 2017, from http://www.sirca.org.sg/wpcontent/uploads/2015/08/Gurumurthy_WhitePaper.pdf

Hagen, E. (2011). Mapping change: Community information empowerment in Kibera (innovations case narrative: Map Kibera). Innovations: Technology, Governance, Globalization, 6(1), 69-94. http://doi.org/10.1162/INOV_a_00059

Hanberger, A. (2009). Democratic accountability in decentralized governance 1. Scandinavian Political Studies, 32(1), 1-22. http://doi.org/10.1111/j.1467-9477.2008.00220.x

Handlykken, A. K. (2012). Exploring the politics of Free/Libre/Open Source Software (FLOSS) in the context of contemporary South Africa; How are open policies implemented in practice? The Journal of Community Informatics, 8(2). 
Hanna, N. K. (2010). e-Transformation: Enabling New Development Strategies (Innovation, Technology, and Knowledge Management). London: Springer.

Hatakka, M., \& Lagsten, J. (2012). The capability approach as a tool for development evaluation - analyzing students' use of internet resources. Information Technology for Development, 18(1), 23-41. http://doi.org/10.1080/02681102.2011.617722

Hodgkinson-Williams, C., Paskevicius, M., Cox, G., Shaikh, S., Czerniewicz, L., \& Lee-Pan, S. (2013). 365 days of openness: The emergence of OER at the university of Cape Town. In R. McGreal, W. Kinuthia, S. Marshall, \& T. McNamara (Eds.), Open Educational Resources: Innovation, Research and Practice (pp. 33-45). Vancouver: Commonwealth of Learning and Athabasca University.

Hofkirchner, W. (2010). Twenty questions about a unified theory of information: A short exploration into information from a complex systems view. Marblehead, MA: ISCE Publishing.

Hoque, M. R., \& Sorwar, G. (2015). ICT based e-government services for rural development: a study of union information and service center (UISC) in Bangladesh. Electronic Journal of Information Systems in Developing Countries, 71(8), 1-19.

Howell, J., \& Pearce, J. (2001). Civil society \& development: A critical exploration. London, UK: Lynne Rienner Pub.

Iyengar, R., Mahal, A. R., Aklilu, L., Sweetland, A., Karim, A., Shin, H., et al. (2015). The use of technology for large-scale education planning and decision-making. Information Technology for Development, 1-14. http://doi.org/10.1080/02681102.2014.940267

Johnstone, J. (2007). Technology as empowerment: A capability approach to computer ethics. Ethics and Information Technology, 9(1), 73-87. http://doi.org/10.1007/s10676-006-9127x.pdf

Jordan, L., \& van Tuijl, P. (Eds.). (2006). NGO Accountability. London, UK: Earthscan Publications Ltd.

Kleine, D. (2010). ICT4what?-using the choice framework to operationalise the capability approach to development. Journal of International Development, 22, 674-692.

Kleine, D. (2013). Technologies of choice?: ICTs, development, and the Capabilities Approach. Cambridge: MIT Press.

Koppell, J. G. (2005). Pathologies of accountability: ICANN and the challenge of "multiple accountabilities disorder." Public Administration Review, 65(1), 94-108.

Korten, D. C. (1990). Getting to the 21st Century: Voluntary action and the global agenda (Kumarian Press library of management for development). West Hartford, CT: Kumarian Press.

Kovacic, P., \& Lundine, J. (2013). Mapping Kibera. Empowering slum residents by ICT. In S. Livingston \& G. Walter-Drop (Eds.), Bits and Atoms: Information and Communication Technology in Areas of Limited Statehood (pp. 115-129). Oxford: Oxford University Press.

Leat, D. (1988). Voluntary organisations and accountability. London: Policy Analysis Unit / Billing \& Sons.

Leonardi, P. M., \& Barley, S. R. (2008). Materiality and change: Challenges to building better theory about technology and organizing. Information and Organization, 18(3), 159-176. 
http://doi.org/10.1016/j.infoandorg.2008.03.001

Meesters, K., \& Van de Walle, B. (2013). Increasing efficiency of humanitarian organizations with volunteer driven information products (pp. 149-158). Presented at the 2014 47th Hawaii International Conference on System Sciences (HICSS), IEEE. http://doi.org/ 10.1109/HICSS.2014.27

Merali, Y., \& McKelvey, B. (2006). Using Complexity Science to effect a paradigm shift in Information Systems for the 21st century. Journal of Information Technology, 21, 211-215.

Michener, G. (2015). Policy evaluation via composite indexes: Qualitative lessons from international transparency policy indexes. World Development, 74(C), 184-196. http:// doi.org/10.1016/j.worlddev.2015.04.016

Murillo, M. J. (2015). Evaluating the role of online data availability: The case of economic and institutional transparency in sixteen Latin American nations. International Political Science Review, 36(1), 42-59. http://doi.org/10.1177/0192512114541163

Nussbaum, M. C. (2000). Women and human development: The Capabilities Approach. Cambridge: Cambridge University Press.

Ohemeng, F. L. K., \& Ofosu-Adarkwa, K. (2015). One way traffic: The open data initiative project and the need for an effective demand side initiative in Ghana. Government Information Quarterly, 32(4), 1-10. http://doi.org/10.1016/j.giq.2015.07.005

Oliver, D. (1991). Government in the United Kingdom. Milton Keynes: Open University.

Oosterlaken, I. (2011). Inserting technology in the relational ontology of Sen's Capability Approach. Journal of Human Development and Capabilities, 12(3), 425-432. http:// doi.org/10.1080/19452829.2011.576661

Orlikowski, W. J. (2007). Sociomaterial practices: Exploring technology at work. Organization Studies, 28(9), 1435-1448. http://doi.org/10.1177/0170840607081138

Orlikowski, W. J., \& Baroudi, J. J. (1991). Studying information technology in organizations: Research approaches and assumptions. Information Systems Research, 2(1), 1-28. http:// doi.org/10.1287/isre.2.1.1

Panek, J., \& Sobotova, L. (2015). Community mapping in urban informal settlements: Examples from Nairobi, Kenya. Electronic Journal of Information Systems in Developing Countries, 68(1), 1-13.

Parfitt, B., Parsons, O., Gregory, J., Chiteri, E., \& Omondi, N. (2013). Mapping a blankspot: Introducing OpenStreetMap to Ugunja, western Kenya. London: Ugunja Community Resource Centre, University of London and the Royal Geographic Society.

Pomerantz, J., \& Peek, R. (2016). Fifty shades of open. First Monday, 21(5), 80-85. http:// doi.org/10.1038/scientificamerican1210-80

Poveda, S., \& Roberts, T. (2017). Critical agency and development: Applying Freire and Sen to ICT4D in Zambia and Brazil. Information Technology for Development.

Ramalingam, B. (2013). Aid on the edge of chaos: Rethinking international cooperation in a complex world. Oxford: Oxford University Press.

Raman, B. (2012a). The rhetoric of transparency and its reality: Transparent territories, opaque power and empowerment. The Journal of Community Informatics, 8(2). 
Raman, N. V. (2012b). Collecting data in Chennai city and the limits of openness. The Journal of Community Informatics, 8(2).

Rangaswamy, N., \& Nair, S. (2011). The PC in an Indian urban slum: Enterprise and entrepreneurship in ICT4D 2.0. Information Technology for Development, 18(2), 163-180. http://doi.org/10.1080/02681102.2011.643211

Reilly, K. M. A., \& Smith, M. L. (2013). The emergence of open development in a network society. In M. L. Smith \& K. M. A. Reilly (Eds.), Open Development: Networked Innovations in International Development (pp. 15-50). Ottawa: The MIT Press and International Development Research Centre.

Reilly, K., \& Alperin, J. P. (2016). Intermediation in open development: A knowledge stewardship approach. Global Media Journal, 9(1), 51-71.

Rihani, S. (2002). Implications of adopting a complexity framework for development. Progress in Development Studies, 2(2), 133-143.

Roberts, J. (1991). The possibilities of accountability. Accounting, Organizations and Society, 16(4), 355-368. http://doi.org/10.1016/0361-3682(91)90027-C

Roberts, J., \& Scapens, R. (1985). Accounting systems and systems of accountability understanding accounting practices in their organisational contexts. Accounting, Organizations and Society, 10(4), 443-456. http://doi.org/10.1016/0361-3682(85)90005-4

Roberts, T. (2016). Critical-Agency in ICT4D: a case study of Zambian women's use of participatory video technology to challenge gender inequality. $\mathrm{PhD}$ Thesis. University of London, Egham.

Robeyns, I. (2003). The capability approach: An interdisciplinary introduction. Amsterdam: University of Amsterdam.

Robeyns, I. (2005). The Capability Approach: A theoretical survey. Journal of Human Development, 6(1), 93-117. http://doi.org/10.1080/146498805200034266

Sadoway, D., \& Shekhar, S. (2014). (Re) prioritizing citizens in smart cities governance: Examples of smart citizenship from urban India. The Journal of Community Informatics, 10(3).

Saldana, J. (2009). The coding manual for qualitative researchers. London: Sage Publications Ltd.

Schmandt, J., Ward, C. H., \& Hastings, M. (Eds.). (2000). Sustainable development: The challenge of transition. Cambridge, UK: Cambridge University Press.

Sen, A. (2001). Development as freedom. New York: Oxford University Press.

Singh, P. J., \& Gurumurthy, A. (2013). Establishing public-ness in the network: New moorings for development - a critique of the concepts of openness and open development. In M. L. Smith \& K. M. A. Reilly (Eds.), Open Development: Networked Innovations in International Development (pp. 173-196). Ottawa: The MIT Press and International Development Research Centre.

Smith, M. L., \& Elder, L. (2010). Open ICT ecosystems transforming the developing world. Information Technologies \& International Development, 6(1), 65-71.

Smith, M. L., \& Reilly, K. M. A. (2013). Introduction. In M. L. Smith \& K. M. A. Reilly (Eds.), Open Development: Networked Innovations in International Development (pp. 1-14).

Ottawa: The MIT Press and International Development Research Centre. 
Smith, M. L., \& Seward, R. K. (2017). Openness as social praxis. First Monday, 22(4).

Smith, M. L., Elder, L., \& Emdon, H. (2011). Open development: a new theory for ICT4D. Information Technologies \& International Development, 7(1), iii-ix.

Stahl, B. C. (2008). Information systems: Critical perspectives. London: Routledge.

Stephan, A. (1997). Armchair arguments against emergentism. Erkenntnis, 46(3), 305-314. http://doi.org/10.1023/A:1005329315666

Thompson, M. (2008). ICT and development studies: Towards development 2.0. Journal of International Development, 20, 821-835. http://doi.org/doi:10.1002/jid

Tom-Aba, D., Olaleye, A., Olayinka, A. T., Nguku, P., Waziri, N., Adewuyi, P., et al. (2015). Innovative technological approach to ebola virus disease outbreak response in Nigeria using the Open Data Kit and Form Hub technology. Plos One, 10(6), e0131000-7. http:// doi.org/10.1371/journal.pone. 0131000

United Nations. (2015). Transforming our world: The 2030 agenda for sustainable development. Resolution adopted by the General Assembly on 25 September 2015. New York: United Nations.

Unwin, T. (2007). No end to poverty. Journal of Development Studies, 43(5), 929-953. http:// doi.org/10.1080/00220380701384596

van der Boor, P., Oliveira, P., \& Veloso, F. (2014). Users as innovators in developing countries: The global sources of innovation and diffusion in mobile banking services. Research Policy, 43(9), 1594-1607. http://doi.org/10.1016/j.respol.2014.05.003

Van Der Windt, P. (2013). From crowdsourcing to crowdseeing: The cutting edge of empowerment? In S. Livingston \& G. Walter-Drop (Eds.), Bits and Atoms: Information and Communication Technology in Areas of Limited Statehood (pp. 144-156). Oxford: Oxford University Press.

Van Rooy, A. (Ed.). (2009). Civil society and the aid industry. London, UK: Earthscan Publications Ltd.

van Schalkwyk, F., Willmers, M., \& McNaughton, M. (2015). Viscous open data: The roles of intermediaries in an open data ecosystem. Information Technology for Development, 1-16. http://doi.org/10.1080/02681102.2015.1081868

Vidolov, S. (2014). Collaborative re-orderings in humanitarian aid networks. In N. Bellamine Ben Saoud, C. Adam, \& C. Hanachi (Eds.), Information Systems for Crisis Response and Management in Mediterranean Countries (Vol. 196, pp. 120-134). Cham: Springer International Publishing.

Walsham, G. (2005). Critical engagement: Why, what and how? In D. Howcroft \& E. Trauth (Eds.), Handbook of Critical Information Systems Research: Theory and Application (pp. 225-243). Cheltenham: Edward Elgar Publishing Limited.

Williams, S., Marcello, E., \& Klopp, J. M. (2013). Toward open source Kenya: Creating and sharing a GIS database of Nairobi. Annals of the Association of American Geographers, 104(1), 114-130. http://doi.org/10.1080/00045608.2013.846157

World Bank. (n.d.). Country and lending groups | data. Retrieved December 22, 2017, from http://data.worldbank.org/about/country-and-lending-groups

Young, C. (2014). HarassMap: Using crowdsourced data to map sexual harassment in Egypt. 
Technology Innovation Management Review, 4(3).

Zheng, Y., \& Stahl, B. C. (2011). Technology, capabilities and critical perspectives: What can critical theory contribute to Sen's capability approach? Ethics and Information Technology, 13(2), 69-80. http://doi.org/10.1007/s10676-011-9264-8

Zheng, Y., \& Walsham, G. (2008). Inequality of what? Social exclusion in the e-society as capability deprivation. Information Technology \& People, 21(3), 222-243. http://doi.org/ $10.1108 / 09593840810896000$ 


\section{Appendix - Keywords and article search method}

\section{Search Methods}

We came up with keywords to search for literature during a brainstorming session and we identified 24 terms associated with open development (see Table 1). The keywords are divided into three sections, based on Smith's (2015) taxonomy of open development.

Search keywords

\begin{tabular}{|c|c|c|}
\hline Thing & Process & $\begin{array}{l}\text { An assemblage of things } \\
\text { and processes }\end{array}$ \\
\hline $\begin{array}{l}\text { Open educational resources } \\
\text { Open Internet } \\
\text { Open source software } \\
\text { Open data } \\
\text { Open hardware }\end{array}$ & $\begin{array}{l}\text { Open participation } \\
\text { Open collaboration } \\
\text { Open learning } \\
\text { Open sharing } \\
\text { Open content creation } \\
\text { Peer production } \\
\text { Crowdsourcing } \\
\text { Open knowledge sharing } \\
\text { Open governance }\end{array}$ & $\begin{array}{l}\text { Open development } \\
\text { Open access } \\
\text { Open education } \\
\text { Open health } \\
\text { Open government } \\
\text { Open society } \\
\text { Open innovation } \\
\text { Digital commons } \\
\text { Peer } 2 \text { peer/peer-to-peer } \\
\text { Open science }\end{array}$ \\
\hline
\end{tabular}

Source: Adapted from Smith's (2015) taxonomy.

Using the keywords in Table 1, we searched the Scopus database for relevant articles. Four ICT4D journals (EJISDC, Information Technology in International Development, Information Technology and Development and Journal of Community Informatics) were also searched and screened individually using the same keywords and inclusion and exclusion criteria.

\section{Inclusion and Exclusion Criteria}

We included articles in this review when they met the following criteria: any study that related explicitly to open development, and those that studied themes and practices relating to open development. Themes and practices were drawn from Smith and Elder (2010). This means that we included research that concerned digitally-enabled openness in the context of development, however development is defined. We included peer-reviewed and non-peer reviewed literature. Any article, conceptual or empirical, was included but only if it took place or referenced low- or middle-income countries as categorized by the World Bank (2016). References to developing countries and/or developing regions were also included. Articles in all languages were included; however there were only seven articles in Spanish and two in Portuguese. All other articles were written in English. We excluded research that did not reference openness through ICTs specifically. We excluded technical research if authors did not make links to LMIC contexts in either a general or specific sense. 